\title{
CAD in interdisciplinary integration as a tool to increase specialist training quality in "Construction" education
}

\author{
Anatoliy Bedov ${ }^{1}$, Azat Gabitov ${ }^{2}$, Askar Gaisin ${ }^{2}$, Aleksandr Salov ${ }^{2 *}$, Anastasiia Chernova ${ }^{2}$ \\ ${ }^{1}$ Moscow State University of Civil Engineering, Yaroslavskoe shosse, 26, Moscow, 129337, Russia \\ ${ }^{2}$ Ufa State Petroleum Technical University", Ufa, Russia, 450080
}

\begin{abstract}
Subject: subject of research is characterized by the requirement to master and efficiently apply CAD tools in the teaching process for analyzing reinforced concrete structures and engineering of facilities to be built under current construction standards and regulations.

Objectives: consideration and analysis of updated software applications for simulation enabling to reduce academic load and improve process of education for less period of time. Methods of teaching such subjects as "Reinforced concrete and masonry structures" and "Construction engineering" are improving together with updating of simulation software, meaning consideration of the process for problem solving in calculations, engineering and mounting of reinforced frame elements to one-storey industrial facilities.

Materials and methods: scientific papers by authors of this work were used as reference literature, the article methodology is based on standards of objectivity and development, statistical level of methodological analysis was applied.

Results: comprehensive description for getting modern IT learning skills in using software simulation facilities was prepared under analysis of the below mentioned materials. Problems in making 3D simulation model of a frame of a building considering facilitation for the students in their appreciation and maximum approach to actual behavior of structures were reviewed either. In the course of analysis a number of assumptions was proposed for engineering of connection between bearing elements of the frame and statistical estimation in linear statement.

Conclusions: bases for calculation, engineering and mounting of reinforced concrete structures were considered therewith in accordance with present norms and regulations. Currently a problem in making simulation algorithm for 3D calculation scheme of standard frame to onestorey industrial facilities is still very important.
\end{abstract}

${ }^{*}$ Corresponding author: salov@ list.ru 


\section{Introduction}

Construction branch is one of the key fund-creating industries that is greatly influencing on the Russia economy [1,2]. Further development of the construction industry stimulating new modern innovation technologies and materials results in complication of engineering solutions, with commissioning thereof being prevented from by insufficient qualification of design engineers. One of the reasons is non-compliance of teaching bachelors, masters and specialists with current requirements. To meet the demands of current economy and to comply with changing requirements of the society by each student, the RF program "Development of Education" for 2013-2020 (http://government.ru/programs/202/events/) puts forward an objective to upgrade both contents and technologies of the vocational education. Therefore it is necessary to develop technologies for interdisciplinary integration in all steps of training highly-skilled specialists in "Construction" education.

Nowadays, opportunities of modern software applications are not fully disclosed in the education process of construction institutions of Russia. This issue is especially important due to elaboration and continuous updating of current software applications for modernization of construction branch. Application of IT technologies in CAD enables to greatly increase level and quality of the work to be done, to reduce construction period and costs. Application of IT design tools is also able to provide for wider opportunities for building facilities under the data obtained.

Transition to layered system of higher education provides for realization of different events, with updating of the educational materials being the most important one therewith.

Current training manuals for students in "Reinforced concrete and masonry structures" course over dozens of years still use standard engineering approach in calculations. Less attention is paid to using of modern software applications in education process which is of vital importance due to development of wide spectrum of programs and continuous updating and expansion of opportunities thereof [3, 4]. Appearing training manuals and books $[5,6]$ devoted to CAD are very popular with students and not always may satisfy the demands if used in educational process.

These provisions make students learn methods for reinforced concrete structures calculation under current norms and rules with efficient use of modern software engineering applications. In spite of the problems being clearly set, the process is quite complicated and contradictory [7,8]. On the one hand, reduction of teaching process in Bachelor's education results in reduction of hours in almost all subjects being taught. Here, application of IT and communication technologies is successful by learning more for less period of time. On the other hand, theoretical learning of compulsory minimum in combination with the skills of software application user leads to intensification of the teaching process $[9,10]$. All kinds of teaching aids and recommendations aimed at efficient combination of both in the national educational standard are considered by the authors as useful in solving problems set above $[11,12]$.

\section{Materials and methods}

Mechanism of teaching subject "Reinforced concrete and masonry structures" in Institute of Architecture and Civil Engineering at Ufa State Petroleum University is based on the principle of well-balanced sequential process for considering problems of engineering reinforced concrete frame to one-storey industrial facility [13, 14], being an object of both term papers and graduation design engineering in engineering training of builders for the last several dozens of years.

Programs providing automated solutions procedure (documentation) for the construction technology and construction management both in the site, on the whole, and 
for separate process complicated operations, in particular, reinforced concrete frame making technology (Fig.1) [13, 14], are supposed to be used in the first step of making flow diagrams within "Construction technology" subject. These programs are the database for methodology in making the working plan in the construction site.

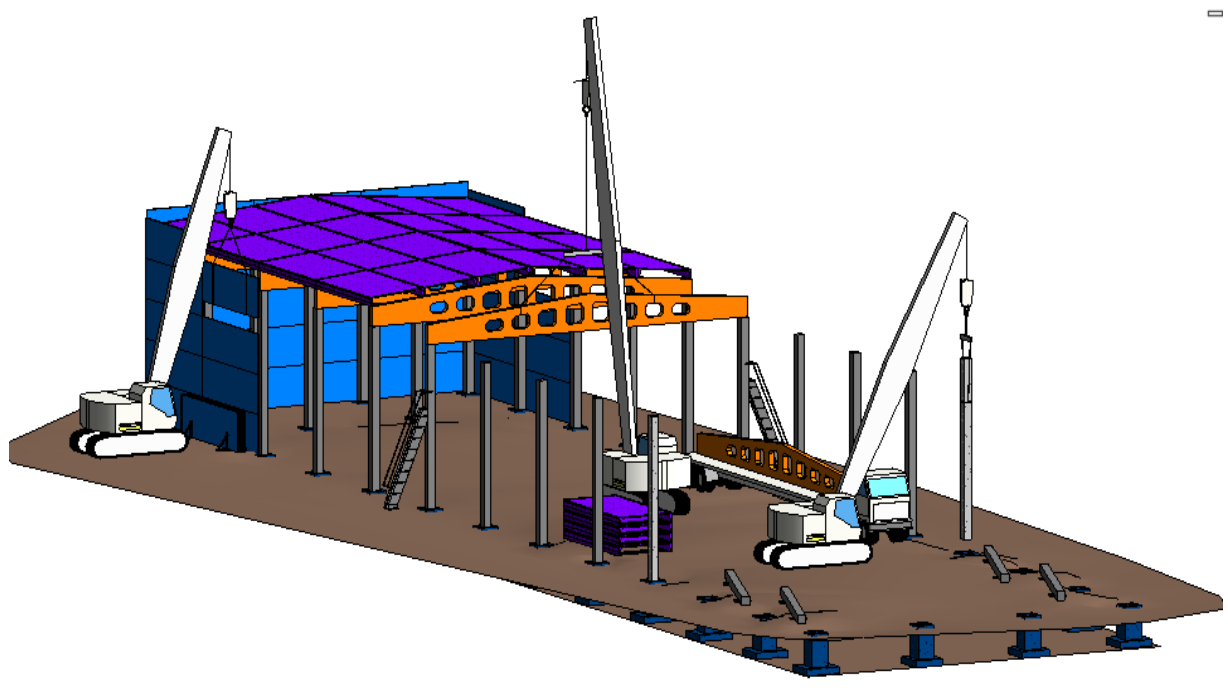

Fig.1. 3D model of flow diagram

Structural engineering of transverse bents for the frame to one-storey industrial facility should be considered further.

The problem is divided into four consequently interrelated steps:

1. Static analysis and design engineering of structural elements of the frame by traditional method (version 1 - "manual" calculation of plane bent). Calculation model is given in Fig.2.

2. SCAD software application $[15,16,17]$ to solve problems of the $1^{\text {st }}$ step (version 2 - automated static analysis and engineering of flat transverse bent of the frame). Finiteelement model is given in Fig.3.

3. Making 3D model of the frame in SCAD and analysis of stress and strain behavior of bearing elements (version 3 - automated analysis and engineering of 3D problem).

4. Comparative analysis of the results obtained.

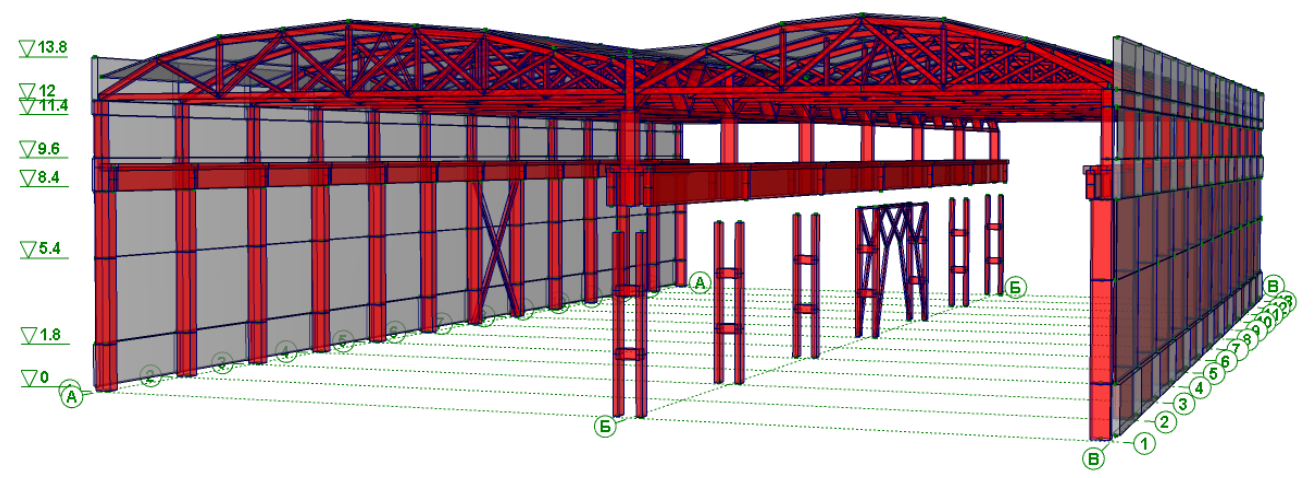

Fig.2. Calculation model 


\section{Research data}

The first step (version 1) is paid special attention to in manuals $[18,19,20]$ as the most important one. The future structural engineer is unable to work with software engineering tools without learning of "engineering" principles of calculation and design of elements in accordance with local building requirements.
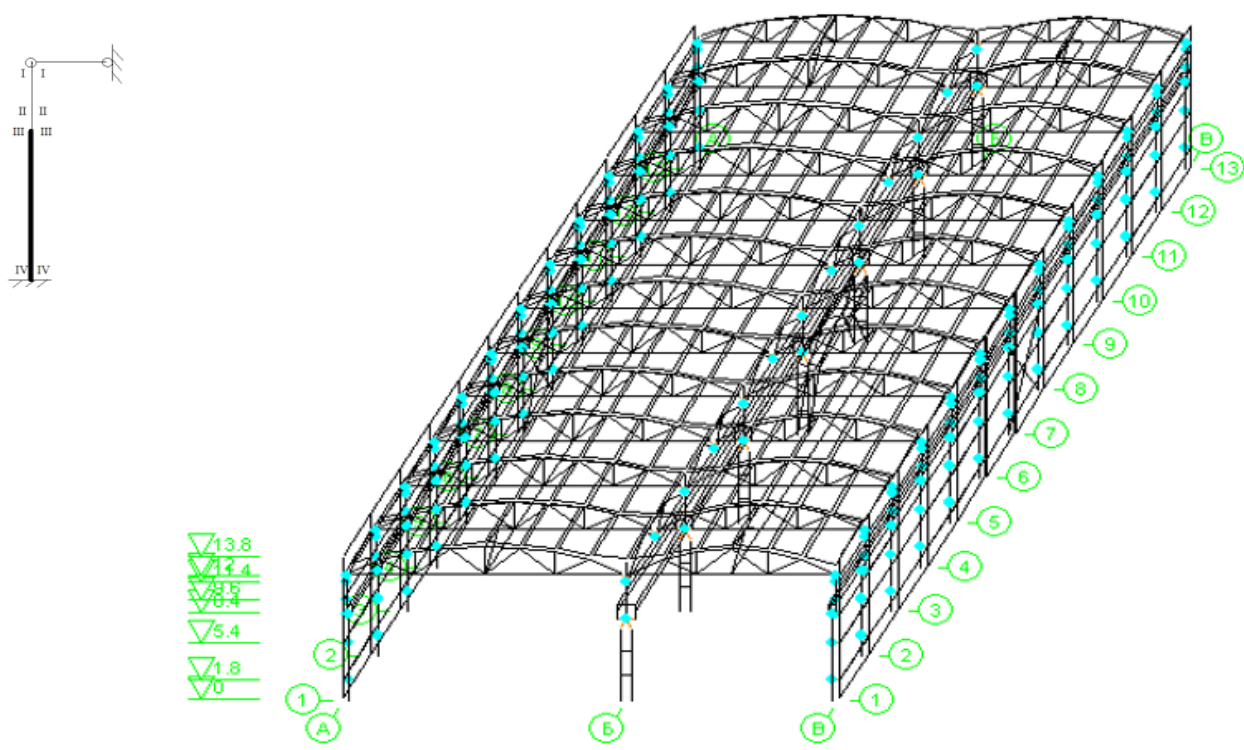

Fig.3. 3D calculation model of the frame

When making 3D calculation model of the frame [21, 22] (version 3) to be well understood by the students and with maximum approach to actual behavior of structures the following assumptions are accepted (Fig.2):

1. Bearing elements of 3D frame (columns, roof and eaves beams, crane runway beams, and bracing) are taken as axial elements (type 5);

2. Enclosing structures (curtain wall panels, glass fixing, roof slabs) are taken as plate (shell) elements (type 44);

3. Simulation of connection between bearing elements of the frame $[23,24]$ is made by solid bodies (type 100);

4. Method for combining relocations is applied to provide for mutual operation of frame elements;

5. Static analysis is made by standard method;

6. Elongated elements affected by external load are conditionally indicated as elements with stiffness properties of reinforced concrete unstressed elements [25];

7. Crane runway beams are accepted as split with vertical load transmissions from crane through the wall, while horizontal load - to columns through top flange;

8. Pivotally connected reinforced concrete roof planks lie on panel points and get into operation together with rafter parts of a roof;

9. Bracing along the frame is made as simple frame metal constructions;

10. Conditionally there are no non-bearing cross walls because a temperature module of specified length $(72 \mathrm{~m})$ is analyzed. 


\section{Conclusion and discussion}

Static analysis results of three analytical model versions of the frame to one-storey industrial facility consisting of two unequal spans with different column space along external and internal axles have revealed that stress and strain behavior of basic bearing structures by version 1 and 2 (plane model) and version 3 (3D model) has distinctions both in kind and degree (table 1). Such distinctions are explained by approaches assumed and assumptions in defining the rules for making analytical model to each version.

An attempt to make an algorithm for simulation of 3D calculation model of standard frame to one-storey industrial facility gave absolutely no answers but raised many interesting problems to be thoroughly studied in special courses by MA programs "Industrial and Civil Engineering", "Engineering and Construction of Buildings \& Facilities for Petroleum Industry", "Technology of Construction Procedure, Efficient Application of Materials and Structures" in "Construction" education.

Table 1. Applied load in edge column section along A axis

\begin{tabular}{|c|c|c|c|c|c|c|c|c|c|}
\hline \multirow[t]{3}{*}{ Load } & \multirow{3}{*}{$\begin{array}{c}\text { Analytical } \\
\text { model }\end{array}$} & \multirow{3}{*}{$\begin{array}{c}\text { Loading } \\
\text { No. }\end{array}$} & \multicolumn{7}{|c|}{ Sections and applied load $(\mathrm{kN}, \mathrm{kN} * \mathrm{~m})$} \\
\hline & & & \multicolumn{2}{|c|}{ III-II } & \multicolumn{2}{|c|}{ III-III } & \multicolumn{3}{|c|}{ IV-IV } \\
\hline & & & $\mathrm{N}$ & $\mathrm{M}$ & $\mathrm{N}$ & $\mathrm{M}$ & $\mathrm{N}$ & $\mathrm{M}$ & $\mathrm{Q}$ \\
\hline 1 & 2 & 3 & 4 & 5 & $\overline{6}$ & 7 & 8 & 9 & 10 \\
\hline \multirow{3}{*}{$\begin{array}{l}\text { Dead } \\
\text { load }\end{array}$} & manual & $\overline{-}$ & 303,37 & 6,11 & 380,28 & $-33,68$ & 455,18 & 16 & $-5,95$ \\
\hline & plane bent & 1 & 303,37 & 5,73 & 455,18 & $-34,06$ & 455,18 & 14,79 & $-5,85$ \\
\hline & block & $11+5$ & 324,83 & $-0,64$ & 418,98 & $-39,24$ & 518,55 & 15,1 & $-4,16$ \\
\hline \multirow{3}{*}{$\begin{array}{c}\text { Snow, } \\
\text { vers.1 } \\
\text { uniform } \\
\text { loading }\end{array}$} & manual & - & 218,88 & 9,85 & 218,88 & $-25,18$ & 218,88 & 3,68 & $-3,46$ \\
\hline & plane bent & 2 & 218,88 & 9,57 & 218,88 & $-25,45$ & 218,88 & 2,81 & $-3,38$ \\
\hline & block & 3 & 220,2 & 2,15 & 220,2 & $-33,92$ & 220,2 & $-19,54$ & $-1,73$ \\
\hline \multirow[t]{3}{*}{$\begin{array}{c}\text { Crane } \\
\text { Dmax A }\end{array}$} & manual & - & 0 & $\begin{array}{c}- \\
33,95\end{array}$ & 245,43 & 64,22 & 245,43 & $-10,39$ & 8,94 \\
\hline & plane bent & 5 & 0 & $\begin{array}{c}- \\
33,70\end{array}$ & 245,43 & 64,47 & 245,43 & $-9,59$ & 8,87 \\
\hline & block & 6 & 0,71 & $\begin{array}{c}- \\
28,57\end{array}$ & 341,83 & 86,66 & 341,83 & $-18,20$ & 12,59 \\
\hline \multirow[t]{3}{*}{$\mathrm{T}, \mathrm{A}$} & manual & - & 0 & $\pm 9,57$ & 0 & $\pm 9,57$ & 0 & $\pm 24,63$ & $\pm 8,19$ \\
\hline & plane bent & 6 & 0 & $\pm 8,98$ & 0 & $\pm 8,98$ & 0 & $\pm 26,49$ & $\pm 4,25$ \\
\hline & block & 8 & 1,25 & $\pm 7,28$ & 1,25 & $\pm 15,13$ & 1,25 & $\pm 35,33$ & $\pm 6,06$ \\
\hline \multirow{3}{*}{$\begin{array}{l}\text { Wind } \\
\text { loading, } \\
\text { left }\end{array}$} & manual & - & 0 & 3,07 & 0 & 3,07 & 0 & 67,66 & $-12,5$ \\
\hline & plane bent & 3 & 0 & 4,76 & 0 & 4,76 & 0 & 73,08 & $\begin{array}{c}- \\
12,94\end{array}$ \\
\hline & block & 1 & 0,06 & 0,26 & 0,06 & 0,76 & 0,06 & 55,61 & $-9,80$ \\
\hline \multirow{3}{*}{$\begin{array}{l}\text { Wind } \\
\text { loading, } \\
\text { right }\end{array}$} & manual & - & 0 & $-6,68$ & 0 & $-6,68$ & 0 & $-57,51$ & 9,06 \\
\hline & plane bent & 4 & 0 & $-8,28$ & 0 & $-8,28$ & 0 & $-62,65$ & 9,49 \\
\hline & block & 2 & 0,03 & 0,26 & 0,03 & $-4,21$ & 0,03 & $-46,35$ & 7,06 \\
\hline
\end{tabular}

Actual questions are:

Analysis of framing scheme affecting 3D operation under crane loading;

Analysis of stress and strain behavior of roof framework with roof slabs to be included thereto;

Numerical analysis of actual load transfer from unequally deformed roof slabs upon roof framework parts;

Analysis of stress and strain behavior of roof framework with roof slabs to be included thereto in the construction phase and subsequent operation thereof ("MOUNTING" mode); 
Alternate engineering of frames under the given plan with application of different structures (sub-schemes);

Behavior of two-element columns in 3D model is still to be studied.

\section{References}

1. Nidziy Ye N Problems and future development of the Russian construction industry under conditions of economic crisis // MSUCE Bulletin 2016 No5, pp. 119-129.

2. Rakhmankulov DL, Zentsov VN, Gabitov AI, Chanyshev RR History of the origin, formation and development of higher oil education and science in Russia // Dedicated to the 60th anniversary of the Ufa State Petroleum Technical University / Moscow, 2007. V 2 Protection against corrosion by higher petroleum institutions activities.

3. Semenov AA, Gabitov A.I. Design and computing complex SCAD in the educational process. Part 1. Static analysis. Moscow: Publishing House of the Association of Building Universities, 2005. $152 \mathrm{p}$.

4. Gabitov AI, Semenov AA Design and computing complex SCAD in the educational process. Part 2. Application in the calculation of reinforced concrete structures in course and diploma papers. Moscow: Publishing house SCAD SOFT, 2011. 279 p.

5. Bedov AI, Znamensky VV, Gabitov AI Assessment of technical condition, restoration and strengthening of the foundations to building structures of operated buildings and structures. Part 1. Inspection and assessment of the technical condition of the foundations and building structures of operated buildings and structures. M: DIA Publishing House, 2014. 704 p.

6. Bedov AI, Gabitov AI, Znamensky VV Assessment of technical condition, restoration and strengthening of bases and building structures of operated buildings and structures. In 2 parts. Part II. Restoration and strengthening of bases and building structures of operated buildings and structures. Ed. A.I. Bedov: Inst. M: ASB, 2017. 924 p.

7. Rakhmankulov DL, Gabitov AI, Semenov AA, Udalova EA Higher construction education in the Republic of Bashkortostan: historical heritage, experience and development prospects. M.: Inter, 2010. 390 p.

8. Gabitov AI, Semenov AA, Malyarenko AA Methodical support of the educational process in the conditions of GEF 3 for "Reinforced concrete and masonry structures" subject // Ferroconcrete constructions: research, design, teaching methods. Materials of the International Scientific and Methodological Conference dedicated to the 100th anniversary of VN Baikov's birth Moscow: April 4-5, 2012. pp. 60-65

9. Gabitov AI, Gaisin AM, Salov AS Optimization of independent work of students in "Industrial and civil construction" branch in practical classes on special subjects / / Problems of Russian construction industry. Materials of the XXI International Scientific and Technical Conference. 2017. pp. 385-386.

10. Semenov AA, Gabitov AI, Malyarenko AA, Poryvaev IA, Safiullin M.N. SCAD computing complex in the educational process. Static analysis. Moscow: ASV, SCAD SOFT Publishing house, 2013. 238 p.

11. Bedov AI, Gaisin AM, Gabitov AI Computer Modulation of Hollow Tiles Behavior under Load and Masonries Made Thereunder. News of higher educational institutions. Textile industry technology 2017 No 3 (369) pp 231-236.

12. Salov A S, Terekhov I G, Nedoseko I V, Software package "Hector: design-engineer" in design engineering of construction and fuel-and-energy facilities, Ufa USPTU Publishers 2016. 138 p.

13. Pudovkin AN, Gabitov AI, Salov AS, Chernova A.R. Program for calculating the grain size and grain composition of sand: Certificate of state registration of the computer 
program No. 2018617134 / right holder FGBUU from UGNTU; claimed. 24/04/2018; reg. 06/19/2018

14. Bedov AI, Gabitov A.I. Designing, restoration and strengthening of rock and reinforced masonry structures: Textbook. Moscow: DIA Publishing House, 2006. 568 p.

15. Gabitov AI, Semenov AA Reinforced concrete structures. Course and diploma papers using SCAD software complex. M.: Publishing house SCAD SOFT, DIA Publishing House, 2011. 280 p.

16. Bedov AI, Gabitov A.I. Engineering structures of a tower type, technological overpasses and power transmission line supports. // Ministry of education and science of the Russian Federation, National research. Moscow State Construction University. Moscow: MSU publishing house, 2017. 328 p.

17. Koval EZ, Ryazanova VA, Roginskaya EL, Ivanov FM Mycodestructions in building structures of internal premises in food industry enterprises / / Microbiological Journal. 1991. V.1991. V.53. No 4. pp. 96-103

18. Bedov AI, Gabitov AI, Salov AS, Gaisin AM, Khabibullina LI Application of computer simulation for optimization of sections of reinforced concrete frame elements / / Construction and reconstruction No. 6 (74) 2017 (November-December). pp. 3-12.

19. Ryazanov AN, Vinnichenko V.I. Investigation of the influence of the organic constituent of coal enrichment cleaning waste on the dolomite decarbonization process // News of Higher Institutions. North-Caucasian region. Series: Engineering. 2014. No. 1 (176). pp.115-117

20. Bedov AI, Gaisin AM, Gabitov AI, Kuznetsov DV, Salov AS, Abdulatipova Ye.M. Comparative evaluation of methods for determining the physico-mechanical characteristics of hollow wall ceramic by modern software systems // Bulletin MGSU. 2017. Volume 12. Issue. 1 (100). Pp. 17-25. DOI: 10.22227 / 1997-0935.2017.1.17-25

21. Salov AS, Khabibullina LI, Gabitov AI, Udalova EA, Timofeev VA, Timofeev AA Historical stages of the origin and development of monolithic construction // History of science and technology. 2017. No. 11. pp. 37-43.

22. Pudovkin AN, Ryazanova VA, Nedoseko IV, Salov A.S. Program for calculating clay content in lumps: Certificate of state registration of PC application No. 2018617277 / copyright holder FGBUU from UGNTU; claimed. 26/04/2018; reg. 06/21/2018

23. Bedov AI, Salov AS, Gabitov AI, CAD methods of structural solutions for reinforced concrete frame // XXI International Scientific Conference on Advances in Civil Engineering "Construction - The Formation of Living Environment" (FORM 2018) 25-27 April 2018, Moscow, Russian Federation. V 365 (2018), 2018. pp 1-8

24. Ryazanov AN, Vinnichenko V.I. Thermodynamic analysis for intensifying the process of magnesium carbonate dissociation with coal component in dolomite // Bulletin of Voronezh State Technical University. Series: Engineering. 2013. V 9. No. 6.2. pp 2224.

25. Salov A.S. Problems of optimum application of high-strength concretes and high grade rebars in bending structures // Proceedings of XV Academic Readings of RAASN - an international scientific and technical conference. Achievements and problems of materials science and modernization of the construction industry. 2010. pp. 58-61. 